12. 磁塔殘閂 九枚解說がない，古記錄には見えないが，亦忽諸に附

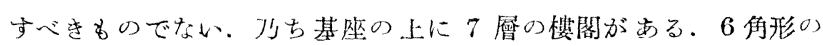
塔です。其の基座は往 5 寸 1 分で，中心ょり針金の心棒が起て」あ り，各厤の中心に公が穿つてあるから，積重福るのです。素地は白 色で，勫薬には壆裂がある。基座は綵白の网釉で斑交を現はし，各

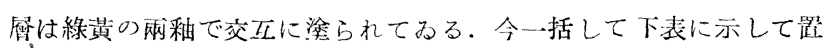
きませら。

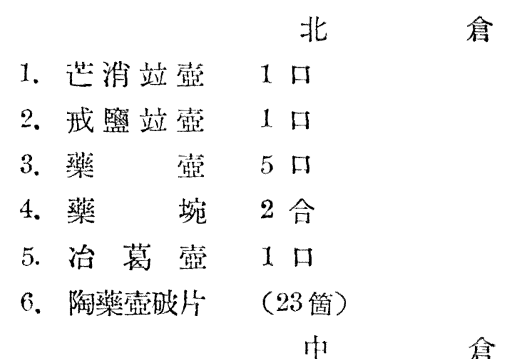

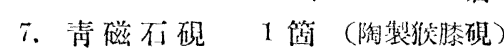
南含
8. 磁

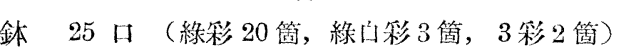
9. 磁
瓶 1 口 (綠白裑)
10. 磁

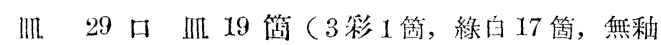
1 筒), 盌 10 筬 ( 3 溹 1 简, 綠白彩 4 䈯，綠彩 5 箇)
11、磁鼓胢
1 简 (化粈 3 稿)
12. 磁塔殘関
( 3 彩)

\section{其五一 正倉院御物特别展雚の一}

世界は沉く，國は許多岁けれど，萬世一系の天皇を戴いてるる ところは, 我が日本の外にはありませぬ、誠に有難い極みで御座い ます。其の一系の第一代の神武天量が，大和の彊原の宮に於て御位 に御郎き遊ばされてより數へて，昨年は筫に 2600 年に當るので， 前後に二つとない御日出度い歲でありました。

政府では 11 月 10 日を卜して窝城外苑に於て，嚴庴なる奉㒭式 を擧げられ，楚日は呵所に於て盛大なる祝賀會を行はれました。其 の外に諸方にて, それぞれ奉祝の式を擧げられ，併せて種々の催物 が行はれました．中に就て奈良正倉院の御物を搬出して，東京上野 公園內なる帝室博物館に陳列して，公踏に拜觀せしめたことは，誠 に適當且つ秀逸の所置でありました.

贸も正倉院の御物を般出して公等の拜觀を許されたことは今们が 最初ではない，明治 8 年 3 月に東大寺の嘴廊に於て，奈良博覽會を 開かれた時に，該御物の，一部の陳列を許された，是れが嚆矢であ る. 炏いで闹 13 年 2 月に同所に於て, 再び博覽會を催了された時 にも陳列を䪨された，是れが第 2 尼であつた，それ故に昨年の放觀

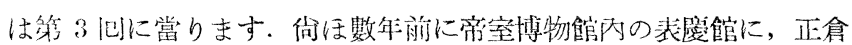
院御物和の染織品を陳列された，之れを加ふれば昨年の放觀は第 4 仙となるのであります。

其の外に放觀は許されないが，該御物を搬出したことは前例があ る. 郎ち明治 25 年に御物整理掛の廳舍は, 趨町佔三作町の舊工部 大學校の校舍跡に置かれて，奈良から御物を搬出して，或は修理を 加へ，或は模造品を作られた。其の事は 14 年間に互つて, 同 38 年 に日露戰爭が脬發したので停止になりました.

\section{其五二 正倉院御物特别展観の二}

昨年の特別展觀に出榢された御物は，中南の兩倉に芼藏されたも のより㽞拔して 144 點を數へた. 之れを全體の 5600 餘點に比すれ ば凡そ 4 分に當る. 其の外に同院御物の模造品が 64 點㟧り, 佾ほ

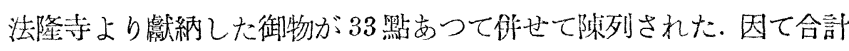
では 241 點となつた.今特別展觀目録によつて略記して見ませう.

第 1 公は武具, 交房具, 交書にて, 㓑引を初筆として 32 點あつ た。

第 2 室は調度にて，暴摤軾を初䇠として，14 點あつた。

第 3 公は調度, 樂器, 繪畫, 衣服, 文畫等にて, 金銀平脫漆皮箱 を初筆として 46 點あつた

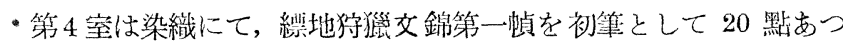
た。

第 5 室は佛具類にて，佛像型 1 枚を初管として 16 點もつた。

第 6 室は佛具類にて, 碧地金銀繪箱を初筆として 16 點あつた.

第 7 室は正合院御物模造にて，䘞䇠の金銀莊唐太刀と共に 13 點 あつた.

第 8 室は同前にて，䘞等の漆繪彈弓と共に 37 點あつた。

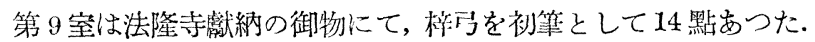

第 10 窒は同前にて初筆は珠玉莊沈香經箱 1 合にて 33 點あつた.

展觀の期間は 11 月 5 日より 24 日に至る 20 日間であつて, 初 日は招待日で，6日より公羕の拜觀を許された。午前 9 㭙に開場し て午後 4 時に閉場したが，大場突の販壹は 3 洔を限りとした.

䝿に千載—遇の事とて, 奈自朝の交化を慕ふ者は，帝都は論なく 遠く北海道，九州は申寸女患か朝鮮，滿洲よりも馸けつけて，其の 光榮に浴したいと詰め寄せた。總計 40 萬人を突破して, 一日本均 2 萬人を數へた。博物館の 1 年閒の本均觀覽者は 37 萬人であるか ら，20日間にて之れを超過したのであつた．而して最終に近くに當 つては, 押しかけた群䍃は蜿蜓として, 博物䬣前より數町を隔てた 公園の大口の邊迄列をなして，洔刻の來るのを俟つてるた４千前 6 、時に赴いて 1.0 時に漸やく入場したところの私の知人もあつた. 又 䨖體入場者の如きは, 先達に引率されて素通り同樣に步行するるので あつた、（昭 16.2.24 受付）
故近藤清治先生謝恩記念會資金募集 本邦工業界，學石界は

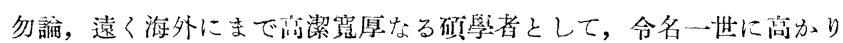

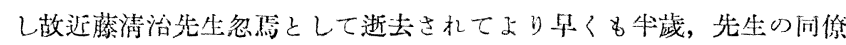
並に知遇熹陶定受けし子弟等の迎葈の念止夕踓きものあり, 相謀りて

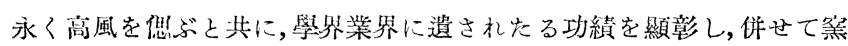
業工學の振興に笴與せんとし, 先生の謝恩記念會を組織し,目下資金を

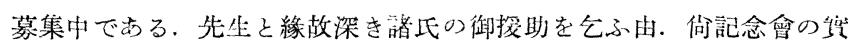
行計畫として，（イ）記念請演會心開催，（口）記念論交集の刊行，

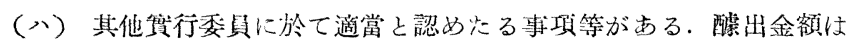

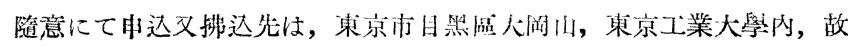
近藤清治先生謝恩記念會宛.

\section{0 號 正 誤}

\begin{tabular}{llr} 
頁 & \multicolumn{2}{c}{ 行 } \\
238 & 右下より & 20 \\
239 & 左上より & 4 \\
" & " & 8 \\
" & 21 \\
240 & 左上より & 4 \\
” & ” & 11 \\
" & 右上より & 12 \\
" & " . & 29
\end{tabular}

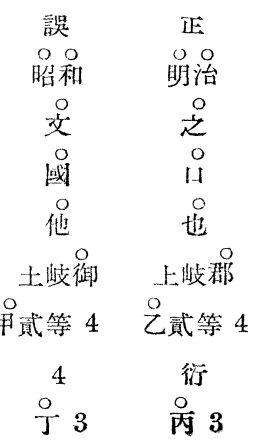

